\title{
Foreword by the Outgoing Editor
}

The publication of this issue signifies the changing of the editorial guard at The China Quarterly. Although I will guest-edit the forthcoming special issue on Contemporary Taiwan (No. 148), it is time to hand over the editorial chair to my successor. This transition is occasioned by my move to the George Washington University to take up the positions of Professor of Political Science and International Affairs, and Director of the Sigur Center for Asian Studies.

Dr Richard Louis Edmonds succeeds me as Editor. Rick is known to many in the China field as one of the world's leading specialists on China's geography and environment. He has taught at the School of Oriental and African Studies, University of London, since 1985, and is presently senior lecturer in the Department of Geography. He is also an established authority on Macau, has done considerable research on Taiwan, and is an accomplished linguist with fluency in both Chinese and Japanese. He brings to the job fresh perspectives and expertise, as well as experience as director of the SOAS Contemporary China Institute and chairman of the editorial board of the Oxford University Press series Studies on Contemporary China. I have confidence that Rick will conscientiously and capably perform the duties and responsibilities of Editor.

Five years is a long time in the life of a quarterly journal. During this period we have published over 200 articles and nearly 1,000 book reviews. We have expanded the size of the journal from 800 to 1,200 pages annually; while this has allowed for the publication of more articles and research notes, we have still been able to accept only a relatively small percentage. Every year approximately 125 manuscripts are submitted to the editorial office, with 25 per cent accepted on average, after a rigorous peer review process by the Editorial Board and other reviewers. I wish to thank members of the Editorial Board for their tireless and meticulous efforts to referee the large volume of manuscripts that flow through the editorial office. Without their efforts, The China Quarterly would not be the premier international scholarly publication on 20thcentury China. The Editorial Board itself has undergone considerable change and expansion over the past five years, and today includes most of the world's leading academic specialists in the field.

During my watch we have been able to bring out a number of special issues on topics of importance: The Chinese Economy in the 1990s; Deng Xiaoping: Portrait of a Chinese Statesman; Greater China: The Next Superpower?; China's Legal Reforms; China's Transitional Economy; China's Military in Transition; and Contemporary Taiwan and Reappraising Republican China (forthcoming in issues 148 and 150 respectively). These have proved very popular with readers and have served to set the state of the field for research on their subject areas. I am also pleased to report that these and former special issues on China and Japan and The Individual and the State have been expanded and updated, and reissued in the aforementioned SOAS Contemporary China Institute/ Oxford University Press series Studies on Contemporary China. Printed in paperback and in large press runs, these are selling extremely well and are proving very popular for teaching adoption. 
In 1995 The China Quarterly marked its 35th year of publication. Issue 143 carried reflective and retrospective essays by the six editors to date. These were first presented at a celebratory symposium at the School of Oriental and African Studies and make for interesting reading about the history of the journal and the field of Chinese studies.

Over the last five years the journal has been able to expand steadily its circulation numbers and readership. Over 500 new subscribers have been added and many lapsed ones have returned. Many - indeed now more than half - are non-academics. While the journal's identity and principal clientele is - and shall always remain - the scholarly community, it is encouraging that the journal is now read by so many in the professional worlds of government, journalism, business, banking, the law and nonprofit public interest organizations. This has been one of my principal goals as editor: to make the journal more "reader friendly" and useful to these communities. I am heartened that such professionals take the time to read The China Quarterly, and hope that many find something of interest in every issue.

Indeed, I have also tried to vary the content of every issue so that there is an interesting mix of topics, themes and commentary. We have increasingly grouped articles together thematically, when appropriate, and have initiated new sections on "Concepts and Methods," "State of the Field," and "Current Issues." We continue to publish occasional book review essays as well as a large number of individual reviews on all subjects and areas in Chinese studies. The "Quarterly Chronicle and Documentation" continues to be a hallmark of the journal, as it serves as an important historical record. Throughout my tenure, and before, this section has been most ably compiled by Robert F. Ash, and I wish to thank him for his unstinting efforts to catalogue the rapid changes every quarter.

During my time in the chair the journal has also had a "facelift" and publishing transition. From 1992 it carried a new laminated and thicker cover, as well as the aforementioned expansion to 1,200 pages per year. In 1993 we entered into an agreement with Oxford University Press to publish, distribute and market the journal, though SOAS remains its owner. This proved to be a smooth transition and profitable partnership, of considerable benefit to the journal.

During my time as Editor, both China and China studies have evolved rapidly. My observations on the changing state of the field are recorded in issue 143 and need not be reiterated here. Suffice it to observe that I find the current generation of scholarship on 20th-century China to be both robust and sophisticated. It is also increasingly international in character, and by attempting to include authors and book reviewers from the world over I have done my best to remain true to the statement on the journal's masthead: an international journal for the study of China. The articles published reflect an increasingly rich empirical source base (documentary, archival, oral and observational), theoretical and comparative perspectives, and analytical rigour. There is no better indication of the state of the field than the pages of The China Quarterly. This 
scholarship not only reflects changes in the academic study of China, but in the region itself. China is in a state of perpetual change, but perhaps never as comprehensively as in recent years. The task of The China Quarterly is to reflect these changes through publishing the highest quality and most current analyses. With such a moving target, this is not easy. The journal has also endeavoured to publish on both historical matters and the constituent parts of "other China" - Taiwan, Hong Kong, Macau and Chinese overseas.

It only remains for me to thank all those involved in publishing The China Quarterly for their efforts. It is truly a collective effort. Editorial assistant Alison Surry has been a superb copy-editor and production co-ordinator, stewarding every word, sentence, paragraph, page and issue through the publication process with characteristic qualities of meticulousness and accuracy. Katie Jukes and Joanne Phillips have assisted in innumerable ways as administrative assistant to the Editor; quite simply neither I nor the journal could have functioned without them. They have been highly professional and cheerful in their work, as all around the world who have had the pleasure of contact can amply testify. Martin Daly, Assistant Secretary for research and publications at SOAS, has also been a constant source of administrative support and seasoned professional advice. The School of Oriental and African Studies has continued to support the journal financially through stringent times, for which I am most grateful. The Editorial Board has served with unstinting energy and professionalism - to all I am truly grateful for your efforts in tackling the mountain of manuscripts over the past five years. I hope you have learned as much in reading them as I have. I must also thank the members of the Executive Committee of the Editorial Board, which meets termly at SOAS and with whom I have consulted regularly. You have helped me navigate through difficult times, issues and personalities.

Finally, I wish to thank the readers of the journal who have been supportive throughout. Your positive feedback and suggestions have been very welcome, and I hope that you have gained as much satisfaction from reading each issue as we have from producing it. It has been a unique privilege and honour to serve The China Quarterly and the field of Chinese studies in this way over the past five years. I trust that all will continue to read and support the journal in the years ahead. Thank you.

David Shambaugh 